\title{
EMPLOYEE PERFORMANCE EFFECT IN PT. "X" COMPANY, UNDER THE IMPACT OF SERVANT LEADERSHIP STYLE AND MOTIVATION
}

\author{
Caesar Benyamin, Febi Panji Prasetyo and Adang Widjana \\ Maranatha Christen University Bandung West Java, Indonesia \\ Email: caesarbenyamin69@gmail.com, febipanji@gmail.com dan \\ Awidjana@gmail.com
}

\begin{abstract}
This research examines $P T$. " $X$ " which engaged in automotive business sector, specifically in two-wheeled automotive under Honda brand. This study aims to determine the effect of servant leadership and work motivation on employee performance at $P T$ " $X$ ". This research provides benefits as material and study or consideration as well as contribution from author for common readers, and particularly as an input for decision makers to improve employee performance at $P T$. " $X$ ". The method quantitative with the approach casusal explanatory by using a questionnaire as a data collection tool. The population of this research is 80 employees. The results shows that there is a positive influence between servant leadership and work motivation on performance.
\end{abstract}

Keywords: servant leadership; work motivation; performance

\section{Introduction}

Human resources are the most important organization asset, which make other organizational resources work (Simamora, 2015). Human resource is an important concern in the globalization era to sustain the company. Achievement, development and progress of the company are mainly determined by the company's performance itself. According to (Sedarmayanti, 2016), PT. "X" is one of large companies in which has been long established and rapidly growing. Established in 1970, PT. "X" started a business in the automotive sector, particularly in two -wheeled automotive under Honda brand. Along with it's development, PT. "X" is trusted by Astra Honda Motor to become the Main Motorcycle Dealer in West Java. During 2018, recorded AHASS under the PT. "X" serves 8.700.135 units of motorcycles. While nationally, PT. "X" had gave contribution of 18.27 percent in 2018. This achievement exceeds from 2017 target.

Performance is a person's achievement result in carrying out assigned tasks under specified criteria. (Moeheriono, 2012) also defines performance as a description of achievement level on implementing certain activity program or policy in creating the goals, objectives, vision and mission of the organization as outlined in the organization strategic planning.

\begin{tabular}{ll}
\hline How to cite: & Caesar Benyamin, Febi Panji Prasetyo and Adang Widjana (2021) Employee Performance Effect In \\
& PT. "X" Company, Under The Impact of Servant Leadership Style and Motivation, Syntax Idea 3(4). \\
& http://dx.doi.org/10.36418/syntax-idea.1106 \\
E-ISSN: & 2684-883X \\
Published by: & Ridwan Institute
\end{tabular}


Various ways will be done by company or organization on improving employee performance. Other factor that can affect employee performance, is the leadership style factor. Leadership is taken from English vocabulary, which is leadership that comes from the definition of to lead which means to (Spears \& Lawrence, 2016), explains that leadership is an additional influence that exceeds and is above the mechanical needs on directing organizational routine. Basically, every leader has a different behavior in leading his followers, the behavior of these leaders is called a leadership style. Leadership has a very close relationship with motivation, because the success of a leader in moving others to achieve predetermined goals is very dependent on authority, and also the leader in creating motivation in every subordinate, colleague or even superior leader itself.

According to (Budiaman, 2011), motivation is a process where the need to encourage someone to carry out a series of activities that lead to the achievement of a goal. The role and function of the leadership style and work environment will lead to work motivation, in which would encourage employees to improve their performance to be better. Apart from work motivation, leadership style and work environment can directly influence performance.

According to (Arsyad, 2011), motivation is a process where the need to encourage someone to carry out a series of activities that lead to the achievement of a goal. The role and function of the leadership style and work environment will lead to work motivation, in which would encourage employees to improve their performance to be better. Apart from work motivation, leadership style and work environment can directly influence performance.

A leader absolutely must understand the background, abilities, needs and expectations of employees where the role of this leadership can be a driving force to improve the performance and work productivity of employees. If the work environment is good and comfortable, it can spur a sense of satisfaction in employees so that employees are able to provide feedback which in turn can have a positive influence on employee performance at the company. Author has distributed pre survey questionnaires to 30 employees of PT. "X" to observe the existing phenomena (Markos \& Sridevi, 2010).

\begin{tabular}{clcc}
\hline No & \multicolumn{1}{c}{ Performance assessment } & Yes & No \\
\hline 1 & Leaders are attracting employees & $30 \%$ & $70 \%$ \\
\hline 2 & Tasks are clearly stated & $60 \%$ & $40 \%$ \\
\hline 3 & $\begin{array}{l}\text { There are several alternative paths to } \\
\text { complete the task }\end{array}$ & $70 \%$ & $30 \%$ \\
\hline 4 & $\begin{array}{l}\text { Leaders are giving example of how to } \\
\text { complete tasks for employees }\end{array}$ & $40 \%$ & $60 \%$ \\
\hline 5 & $\begin{array}{l}\text { Leaders have the authority to provide } \\
\text { reward \& punishment }\end{array}$ & $100 \%$ & $0 \%$ \\
\hline 6 & Leadership has legitimate power & $100 \%$ & $0 \%$ \\
\hline
\end{tabular}


It can be concluded that the majority of employees are positively regards their superiors leadership, even though there are some things that have not been fulfilled. Employees perceive the head of the workshop as not being able to provide influence (influence) in work, providing an example in problem solving.

In addition to the leadership style, the performance of the employee is a benchmark for the emergence of the prime performance needed to serve the community. In the results of the pre-survey conducted, the following data appears:

\begin{tabular}{clcc}
\hline No & \multicolumn{1}{c}{ Performance assessment } & Yes & No \\
\hline 1 & $\begin{array}{l}\text { I can understand the measurement of occured } \\
\text { problem }\end{array}$ & $33 \%$ & $69 \%$ \\
\hline 2 & I am able to solve every problem & $50 \%$ & $50 \%$ \\
\hline 3 & I am able to take lessons from every problem & $85 \%$ & $15 \%$ \\
\hline 4 & I always come to the office on time & $66 \%$ & $34 \%$ \\
\hline 5 & I don't quickly give up on every problem & $60 \%$ & $40 \%$ \\
\hline 6 & I am easy to cooperate & $46 \%$ & $54 \%$ \\
\hline 7 & $\begin{array}{l}\text { I often talk to colleagues about other things } \\
\text { during working hours }\end{array}$ & $77 \%$ & $23 \%$ \\
\hline 8 & $\begin{array}{l}\text { Work result are fulfilling the company } \\
\text { demands }\end{array}$ & $37 \%$ & $63 \%$ \\
\hline 9 & I am able to motivate myself & $33 \%$ & $67 \%$ \\
\hline 10 & I always able to fulfilling the given targets & $47 \%$ & $53 \%$ \\
\hline
\end{tabular}

Referring to the pre survey table above, it can be observed that there are factors which make the employee performance at PT. "X" is low and becomes a problem in the company. Many employees are not able to understand the problems at hand, are not able to motivate themselves and are unable to provide results in accordance with the wishes of the company.

This research purpose is to determine and analyze Servant Leadership style, employee motivation, employee performance and the effect of Servant Leadership and motivation on performance at PT. "X" either simultaneous or partial. A job with certain requirements on it's progress of reaching the goal are known as job standards. An employee is considered successful in carrying out his job or having a good performance, if the work results obtained are higher than the performance standard.

This research is a replication of several studies conducted by (Sapengga, 2016), titled "Pengaruh Servant Leadership terhadap kinerja karyawan PT. Daun Kencana Sakti Mojokerto" ; (Nendah, Mulyatini, \& Yustini, 2021), titled "Pengaruh Servant Leadership terhadap motivasi kerja, kinerja karyawan dan komitmen organisasi". and (Nendah et al., 2021), titled "Pengaruh Servant Leadership terhadap motivasi kerja, kinerja karyawan dan komitmen organisasi".

This research aims to determine the effect of servant leadership and work motivation on employee performance at PT "X". with provides benefits as material and study or consideration as well as contribution from author for common readers, 
and particularly as an input for decision makers to improve employee performance at PT. "X".

\section{Method}

According to (Neuman, 2013), causal is a research based on causative react. While explanatory is a research in which are mainly focused to explain the the reason of how can an event are happened and to form, deepen, extend, or test a theory. Causal explanatory research is a research with determination to learn why and how a variable could affect another variable.

a. Sample Selection and Data Collection

This research was conducted at PT. "X" of Bandung city with employees in the retail department as the research subject. Respondents in this study were 80 people with various levels of positions, including mechanic, front office, salesman / salesgirl, up to supervisor level. According to (Arikunto, 2019), if the population is less than 100 people, the total sample is taken as a whole, but if the population is greater than 100 people, $10-15 \%$ or $20-25 \%$ of the population can be taken. Based on this research, because the total population is not greater than 100 respondents, author take $100 \%$ of the total population at PT. " $\mathrm{X}$ " of which is as many as 80 respondents. By using of the entire population without having to draw the research sample as an observation unit is called a census technique.

b. Research Location

In this case, author conducted research at PT. "X" which is located on J1. Raya Cibeureum, Andir, Bandung. Subjects of this study were mechanical employees at PT. "X". The research object studied is Servant Leadership (X1) and work motivation as an independent variable (X2) and employee performance as a variable (Y).

c. Variable Measurement

- Servant Leadership is defined as leadership that starts from a sincere feeling in the heart that wants to serve, and be the first to serve. Servant Leadership is measured by the instrument developed (Ambali, Suleiman, Bakar, Hashim, \& Tariq, 2011) which consists of 12 question items. The answer choices is using Likert scale which shows 1 which means strongly disagree to 5 which means strongly agree.

- Motivation is the process of generating behavior, maintaining progress in behavior, and channeling specific action behaviors. To this case, motives (needs, wants) encourage employees to act. Motivation is measured by the instrument developed (Maduka \& Okafor, 2014) which consists of 14 question items. The answer choices use a Likert scale which shows 1 which means strongly disagree to 5 which means strongly agree (Sugiyono, 2014).

- Performance is a record of the results obtained from a certain job function during a certain period of time. Performance is measured by the instrument developed (Rohiyah, Sunaryo, \& Rizal, 2020) which consists of 12 question items. The 
Employee Performance Effect in PT. "X" Company, Under The Impact of Servant Leadership Style and Motivation

answer choices use a Likert scale which shows 1 which means strongly disagree to 5 which means strongly agree.

\section{Results and Discussion}

\begin{tabular}{llllll}
\multicolumn{6}{c}{ Respondent Characteristics based on Gender } \\
\hline & & Frequency & Percent & $\begin{array}{c}\text { Valid } \\
\text { Percent }\end{array}$ & $\begin{array}{c}\text { Cumulative } \\
\text { Percent }\end{array}$ \\
\hline Valid & Male & 71 & 88,7 & 88,7 & 88,7 \\
\cline { 2 - 6 } & Female & 9 & 11,3 & 11,3 & 100,0 \\
\cline { 2 - 6 } & Total & 80 & 100,0 & 100,0 & \\
\hline
\end{tabular}

Based on the table above, respondent characteristics based on gender are 80 people, consisting of 71 people or $88.7 \%$ male and 9 people or $11.3 \%$ female.

\begin{tabular}{|c|c|c|c|c|c|}
\hline \multicolumn{6}{|c|}{ Respondent Characteristics based on Service Period } \\
\hline & & Frequency & Percent & $\begin{array}{c}\text { Valid } \\
\text { Percent }\end{array}$ & $\begin{array}{c}\text { Cumulative } \\
\text { Percent }\end{array}$ \\
\hline \multirow[t]{4}{*}{ Valid } & $0-1$ year & 14 & 17,5 & $17,, 5$ & 17,5 \\
\hline & $2-5$ year & 28 & 35,0 & 35,0 & 52,5 \\
\hline & above 5 year & 38 & 47,5 & 47,5 & 100,0 \\
\hline & Total & 80 & 100,0 & 100,0 & \\
\hline
\end{tabular}

Based on the table above, respondent characteristics based on Service Period, from the number of respondents 80 people, it can be seen the majority of them work over 5 years with a total of 38 people (47.5\%), 28 people (35.0\%) work in a span of $2-5$ years and as many as 14 people $(17.5 \%)$ worked under 1 year.

Validity test is used to determine the accuracy level of a measuring instrument in carrying out it's measuring function. The variable $\mathrm{X} 1$ is measured by 12 question items. Following are the results of the validity test for the Servant Leadership (X1) variable.

\begin{tabular}{cccc}
\hline Item No. & $\begin{array}{c}\text { Correlation } \\
\text { Coefficient (r) }\end{array}$ & R Value & Conclusion \\
\hline 1 & 1.00 & 0.3 & Valid \\
\hline 2 & 0.840 & 0.3 & Valid \\
\hline 3 & 0.720 & 0.3 & Valid \\
\hline 4 & 0.758 & 0.3 & Valid \\
\hline 5 & 0.513 & 0.3 & Valid \\
\hline 6 & 0.659 & 0.3 & Valid \\
\hline 7 & 0.401 & 0.3 & Valid \\
\hline 8 & 0.563 & 0.3 & Valid \\
\hline 9 & 0,752 & 0.3 & Valid \\
\hline 10 & 0.808 & 0.3 & Valid \\
\hline 11 & 0.712 & 0.3 & Valid
\end{tabular}


The calculation result of correlation value shows that the Servant Leadership (X1) item in this study is valid. Work motivation variable (X2) is measured with 14 question items. Following are the results of the test for the Work Motivation variable (X2).

\begin{tabular}{cccc}
\hline Item No. & $\begin{array}{c}\text { Correlation } \\
\text { Coefficient }(\mathbf{r})\end{array}$ & R Value & Conclusion \\
\hline 1 & 0.400 & 0.3 & Valid \\
\hline 2 & 0.563 & 0.3 & Valid \\
\hline 3 & 0.400 & 0.3 & Valid \\
\hline 4 & 0.334 & 0.3 & Valid \\
\hline 5 & 0.458 & 0.3 & Valid \\
\hline 6 & 0.720 & 0.3 & Valid \\
\hline 7 & 0.712 & 0.3 & Valid \\
\hline 8 & 0.327 & 0.3 & Valid \\
\hline 9 & 0.334 & 0.3 & Valid \\
\hline 10 & 0.348 & 0.3 & Valid \\
\hline 11 & 0.470 & 0.3 & Valid \\
\hline 12 & 0.334 & 0.3 & Valid \\
\hline 13 & 0.458 & 0.3 & \\
\hline 14 & 0.327 & 0.3 & \\
\hline
\end{tabular}

Source : SPSS calculation result

The calculation results of correlation value shows that the Work Motivation (X2) item in this study is valid. The performance variable $(\mathrm{Y})$ is measured by 14 question items. Following are the results of the test results for the Performance variable (Y).

\begin{tabular}{cccc}
\hline \multirow{2}{*}{ Item No. } & $\begin{array}{c}\text { Correlation } \\
\text { Coefficient }(\mathbf{r})\end{array}$ & r Value & Conclusion \\
\cline { 3 - 4 } & 0.513 & 0.3 & Valid \\
\hline 1 & 0.317 & 0.3 & Valid \\
\hline 2 & 0.400 & 0.3 & Valid \\
\hline 3 & 0.310 & 0.3 & Valid \\
\hline 4 & 0.808 & 0.3 & Valid \\
\hline 5 & 0.348 & 0.3 & Valid \\
\hline 6 & 0.840 & 0.3 & Valid \\
\hline 7 & 0.534 & 0.3 & Valid \\
\hline 8 & 0.433 & 0.3 & Valid \\
\hline 9 & 0.401 & 0.3 & Valid \\
\hline 10 & 0.563 & 0.3 & Valid \\
\hline 11 & 0.341 & 0.3 & Valid \\
\hline 12 & 0.394 & 0.3 & Valid \\
\hline 13 & 0.310 & 0.3 &
\end{tabular}

Source : SPSS calculation result 
The calculation results of the correlation value shows that the item Performance $(\mathrm{Y})$ in this study is valid. This result is indicated by the calculated $r$ value that is greater than $r$ table $(0.3)$.

\begin{tabular}{lc}
\hline Cronbach's Alpha & N of Items \\
\hline .973 & 80 \\
\hline
\end{tabular}

From the results listed in table 5.6, it can be seen that the reliability value of the questionnaire items, with amount 80 items, the figure obtained is 0.973 which is greater than the critical value of 0.6 . These results indicate that the measuring instrument used is reliable.

It can be seen that the score for Servant Leadership is in accordance with the respondent results, was scored 3627 with an average score of 3.78. To find out the location of the Servant Leadership variable category, it can be calculated by means of the maximum score $X$ number of questions $X$ number of respondents $5 \times 12 \times 80=$ 4800. Minimum score $X$ number of questions $X$ number of respondents $=1 \times 12 \times 80=$ 960. Interval distance (maximum index value - minimum index value) / 5. (4800 - 960) / $5=768$. The calculation results show the maximum index value of 4800 , the minimum value of 960, and the interval distance of 768. So, Servant Leadership variable at PT. "X" can be considered as high category.

It can be seen that the score for Work Motivation in accordance with the respondent results is obtaining a score of 4471 with an average score of 3.99. To find out the location of the Work Motivation variable category, it can be calculated by means of the maximum score $X$ the number of questions $X$ the number of respondents. $5 \times 14 x$ $80=5560$. Minimum score index score $X$ number of questions $X$ number of respondents $=1 \times 14 \times 80=1120$. Interval distance (Maximum index value - minimum index value) / 5. (5560 - 1120) / $5=896$ The calculation results show that the maximum index value is 5560, the minimum value is 1120 , and the interval distance is 896 . So, Servant Leadership variable at PT. "X" can be considered as very high category.

It can be seen that the score for performance in accordance with the respondent results is obtaining a score of 3910 with an average score of 4.07. To find out the location of the Performance variable category, it can be calculated by means of the maximum score $X$ the number of questions $X$ the number of respondents. $5 \times 12 \times 80=$ 4800. Minimum value $X$ number of questions $X$ number of respondents $1 \times 12 \times 80=$ 960 Interval distance (Maximum index value - minimum index value) / 5 (4480 - 960) / $5=768$. The calculation results show the maximum index value of 4480 values 960 minimum, and the interval distance is 768 . So, Servant Leadership variable at PT. "X" can be considered as high category. 


\begin{tabular}{|c|c|c|}
\hline & & $\begin{array}{c}\text { Unstandardized } \\
\text { Residual }\end{array}$ \\
\hline $\mathrm{N}$ & & 80 \\
\hline \multirow{2}{*}{$\begin{array}{l}\text { Normal } \\
\text { Parameters }\end{array}$} & Mean & .0000000 \\
\hline & $\begin{array}{l}\text { Std. } \\
\text { Deviation }\end{array}$ & 4.24683731 \\
\hline \multirow{3}{*}{$\begin{array}{l}\text { Most Extreme } \\
\text { Differences }\end{array}$} & Absolute & .111 \\
\hline & Positive & .111 \\
\hline & Negative & -.052 \\
\hline \multicolumn{2}{|c|}{ Test Statistic } & .111 \\
\hline \multicolumn{2}{|c|}{ Asymp. Sig. (2-tailed) } &, $016^{\mathrm{c}}$ \\
\hline
\end{tabular}

Testing using the Kolmogorov-Smirnov (K-S) method on the Statistic Test for the regression model has a score of 0.111 with a p-value of 0.016 . The $\mathrm{p}$-value of the K-S test is greater than the error level $(0.016>0.005)$, so it can be concluded that the residual value of the regression model is normally distributed. It is known that the VIF value for each 10 research variable (1.423) is less than 10 , so it is stated that there is no multicollinearity symptom in the regression model used. The Servant Leadership Heteroscedasticity Test explains that the appearring points are spread randomly and evenly both above and below the number 0 on the $\mathrm{Y}$ axis, so it can be concluded that there is no heteroscedasticity in the Servant Leadership aspect. Heteroscedasticity Test of Work Motivation explains that the dots spread randomly and evenly both above and below the number 0 on the $\mathrm{Y}$ axis, so it can be concluded that there is no heteroscedasticity in the aspect of Work Motivation. The Performance Heteroscedasticity Test explains that the dots are spread randomly and evenly both above and below the number 0 on the $\mathrm{Y}$ axis, it can be concluded that there is no heteroscedasticity in the performance aspect.

The Servant Leadership (X1) variable regression coefficient of 0.228 explains the magnitude of the change in the performance score due to the influence of Servant Leadership, indicating the direction of the relationship is directly proportional. So if there is an increase in the Servant Leadership variable score, the Performance score will increase by 0.228 assuming the other variables are constant or unchanged. So the higher Servant Leadership, it will increase performance. The regression coefficient of 11 Work Motivation variable (X2) of 0.638 explains the magnitude of changes in performance scores due to the influence of work motivation, indicating the direction of the relationship is directly proportional. So if there is an increase in the score of the Work Motivation variable, the Performance score will increase by 0.638 with the assumption that the other variables are constant or unchanged. So the higher the work motivation, the higher the performance. The table below: 
Employee Performance Effect in PT. "X" Company, Under The Impact of Servant Leadership Style and Motivation

\begin{tabular}{|c|c|c|c|c|c|c|}
\hline \multicolumn{7}{|c|}{ ANOVA $^{a}$} \\
\hline \multicolumn{2}{|c|}{ Model } & $\begin{array}{l}\text { Sum of } \\
\text { Squares }\end{array}$ & Df & $\begin{array}{l}\text { Mean } \\
\text { Square }\end{array}$ & $\mathbf{F}$ & Sig. \\
\hline \multirow[t]{3}{*}{1} & Regression & 2973.135 & 2 & 1486.568 & 80.337 &, $000^{\mathrm{b}}$ \\
\hline & Residual & 1424.815 & 77 & 18.504 & & \\
\hline & Total & 4397.950 & 79 & & & \\
\hline
\end{tabular}

Obtained the calculated $F$ value of 80,337 with a significance of 0.000 . To test the previously established hypothesis is done by comparing the Fcount with the Ftable value.

\section{Hypothesis test with Partial}

Coefficients $^{\mathrm{a}}$

\begin{tabular}{|c|c|c|c|c|c|c|}
\hline \multirow{2}{*}{\multicolumn{2}{|c|}{ Model }} & \multicolumn{2}{|c|}{$\begin{array}{l}\text { Unstandardized } \\
\text { Coefficients }\end{array}$} & \multirow{2}{*}{$\begin{array}{l}\text { Standardize } \\
\text { d } \\
\text { Coefficients } \\
\text { Beta }\end{array}$} & \multirow[b]{2}{*}{ t } & \multirow[b]{2}{*}{ Sig. } \\
\hline & & B & $\begin{array}{l}\text { Std. } \\
\text { Error }\end{array}$ & & & \\
\hline & (Constant) & 9.867 & 3.813 & & 2.588 & .012 \\
\hline & Total Servant Leadership & .244 & .070 & .270 & 3.484 & .001 \\
\hline & Morivation Total & .631 & .076 & .644 & 8.317 & .000 \\
\hline
\end{tabular}

Comparing the magnitude of the influence together Servant Leadership and Work Motivation on Performance can be seen from the correlation value and the coefficient of determination (R2). This table is the calculation result of the coefficient of determination for the regression equation obtained.

Model Summary ${ }^{b}$

\begin{tabular}{lllll}
\hline Model & $\mathbf{R}$ & R Square & $\begin{array}{l}\text { Adjusted R } \\
\text { Square }\end{array}$ & $\begin{array}{l}\text { Std. Error } \\
\text { of the } \\
\text { Estimate }\end{array}$ \\
\hline 1 &, $822^{\mathrm{a}}$ & .676 & .668 & 4.302 \\
\hline
\end{tabular}

The influence magnitude of Servant Leadership and Work Motivation on Performance can be seen from the result of determination coefficient (R2) which is 0.676. These results indicate that the effect of Servant Leadership and Work Motivation has an effect on performance of $67.6 \%$, and the rest is influenced by other variables that are not included in the variables examined in this study.

\section{Conclusion}

Based on the results and discussion described in the method section, the results obtained were to determine the effect of Servant Leadership and Work Motivation on Performance at PT. " $\mathrm{X}$ " is concluded as follows:

Overall, first Servant Leadership at PT "X" obtained a total score of 3645 from an ideal score of 4800 , this is supported by the Responsible Morality aspect where the leader dares to impose sanctions on employees who violate and the leader always reminds him to work with the correct process. Second the points of Work Motivation at 
PT "X" obtained a total score of 4471 from the ideal score of 5600, this is supported by the aspect of achievement where employees try to actively seek out developments and actively participate in activities at work. And the last variable performance at PT "X" obtained a total score of 3910 from an ideal score of 5200, this is supported by the Need of Supervision aspect where employees have the initiative to work without having to be supervised and are able to think creatively at work.

Partially, the effect of Servant Leadership on positive performance is 3,484, and the effect of work motivation on performance is 8,317.

Simultaneously, Servant Leadership and Work Motivation have a positive and simultaneous influence on performance with a calculated F value of 80,337. So, it can be proven that there is a significant effect of Servant Leadership and Work Motivation on Performance.

Author provides suggestions for each variable that can be considered by PT. "X", which are:

Fist variable is Servant Leadership, the leader is expected to be able to pay attention to the work done by his subordinates and to initiate an offer of assistance if a subordinate is having difficulties. Superiors can also create special times, where the superiors and subordinates can exchange information about what obstacles they are experiencing. Second variable is Work Motivation, the company is expected to be able to provide opportunities for employees to be able to improve competencies where later employees complete their work properly and from the employee side can accept responsibility by completing work according to their job descriptions and ensuring the results are good. And third variable is Performance, the company is expected to be able to provide encouragement to employees for be able to complete their work on time. 
Employee Performance Effect in PT. "X" Company, Under The Impact of Servant Leadership Style and Motivation

\section{BIBLIOGRAFI}

Ambali, Abdul Raufu, Suleiman, Garoot E., Bakar, Ahmad Naqiyudin, Hashim, Rozalli, \& Tariq, Zahrah. (2011). Servant leadership's values and staff's commitment: policy implementation focus. American Journal of Scientific Research, 13(1), 18-40. Google Scholar

Arikunto, Suharsimi. (2019). Prosedur penelitian suatu pendekatan praktik.

Arsyad, Azhar. (2011). Media Pembelajaran. Jakarta: PT Raja Grafindo Persada. Google Scholar

Budiaman, Deddy. (2011). References. Arsyad, Azhar (2011). Media Pembelajaran. Jakarta: PT. Raja Grafindo Persada. Google Scholar

Maduka, Chukwuma Edwin, \& Okafor, Obiefuna. (2014). Effect of motivation on employee productivity: A study of manufacturing companies in Nnewi. International Journal of Managerial Studies and Research, 2(7), 137-147. Google Scholar

Markos, Solomon, \& Sridevi, M. Sandhya. (2010). Employee engagement: The key to improving performance. International Journal of Business and Management, 5(12), 89. Google Scholar

Moeheriono, Pengukuran Kinerja Berbasis Kompetensi. (2009). Competency Based Human Resource Management. Jakarta: Ghalia Indonesia. Google Scholar

Nendah, Nendah, Mulyatini, Nurdiana, \& Yustini, Iyus. (2021). Pengaruh SERVANT leadership terhadap komitmen organisasi (Studi pada Pegawai Disparbud Kabupaten Pangandaran). Business Management and Entrepreneurship Journal, 2(4), 63-79. Google Scholar

Neuman, W. Lawrence. (2013). Metodologi penelitian sosial: Pendekatan kualitatif dan kuantitatif. Jakarta: PT. Indeks. Google Scholar

Rohiyah, Rohiyah, Sunaryo, Hadi, \& Rizal, M. (2020). Pengaruh gaya kepemimpinan reward, lingkungan kerja dan komitmen organisasi terhadap kinerja karyawan Di Bkd Malang. Jurnal Ilmiah Riset Manajemen, 9(09). Google Scholar

Sapengga, Stephen Eka. (2016). Pengaruh servant leadership terhadap kinerja karyawan pada PT. Daun Kencana Sakti Mojokerto. Agora, 4(1), 645-650. Google Scholar

Sedarmayanti. (2016). Manajemen Sumber Daya Manusia Reformasi Birokrasi dan Manajemen.Google Scholar

Simamora, Henry. (2015). Manajemen Sumber Daya Manusia. Yogyakarta: STIEY. Google Scholar 
Caesar Benyamin, Febi Panji Prasetyo and Adang Widjana

Spears, Larry C., \& Lawrence, Michele. (2016). Practicing servant-leadership: Succeeding through trust, bravery, and forgiveness. John Wiley \& Sons. Google Scholar

Sugiyono. (2014). Metode Penelitian Pendidikan Pendekatan Kuantitatif, Kualitatif Dan R\&D. Bandung: Alfabeta. Google Scholar

\section{Copyright holder :}

Caesar Benyamin, Febi Panji Prasetyo and Adang Widjana (2021)

\section{First publication right :}

Journal Syntax Idea

This article is licensed under:

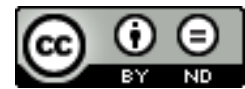

